\title{
Immune response against rickettsiae: lessons from murine infection models
}

\author{
Anke Osterloh ${ }^{1}$ (D
}

Received: 15 July 2017 / Accepted: 20 July 2017 / Published online: 2 August 2017

(c) The Author(s) 2017. This article is an open access publication

\begin{abstract}
Rickettsiae are small intracellular bacteria that can cause life-threatening febrile diseases. Rickettsioses occur worldwide with increasing incidence. Therefore, a vaccine is highly desired. A prerequisite for the development of a vaccine is the knowledge of the immune response against these bacteria, in particular protective immunity. In recent years murine models of rickettsial infections have been established, and the study of immune response against rickettsiae in mice provided many new insights into protective and pathological immune reactions. This review summarizes the current knowledge about immune mechanisms in protection and pathology in rickettsial infections.
\end{abstract}

Keywords Rickettsiae · Immunity · Immunopathology

\section{Introduction}

\section{Rickettsioses}

Rickettsioses are emerging and reemerging febrile diseases that are caused by small obligate intracellular bacteria of the family of Rickettsiaceae. Rickettsiaceae are currently divided into two genera, Rickettsia and Orientia, and a third genus (Occidentia) has recently been proposed [1]. While Orientia (O.) tsutsugamushi is the only member of the genus Orientia and the causative agent of scrub typhus, the genus Rickettsia is further dIvided into four major groups. The vast majority of approximately 20 rickettsial species belongs to the spotted

Anke Osterloh

osterloh@bni-hamburg.de

1 Bernhard Nocht Institute for Tropical Medicine, Hamburg, Germany fever group (SFG), e.g. Rickettsia $(R)$. rickettsii and $R$. conorii, the causative agents of Rocky Mountain spotted fever (RMSF) and Mediterranean spotted fever (MSF). R. prowazekii and $R$. typhi are the members of the typhus group (TG) of rickettsiae. These bacteria cause epidemic and endemic typhus, respectively. $R$. felis, $R$. akari and $R$. australis belong to the transitional group of pathogenic rickettsiae while members of the ancestral group ( $R$. bellii, $R$. canadensis) are non-pathogenic [2-4]. Rickettsiae are transmitted to humans by arthropod vectors and enter the body during the blood meal of the arthropod. Table 1 provides an overview of the genera Rickettsia and Orientia, vectors and natural reservoirs, the disease that is induced by different rickettsial species and their distribution (Table 1).

Rickettsiae infect endothelial cells (ECs) that coat the inner wall of the blood vessels. These cells are considered the dominant target cells of rickettsiae [3, 6]. The bacteria are taken up by endocytosis and rapidly escape from the endosome by endosomal lysis [7-11]. Rickettsiae then replicate free in the cytosol until release by different mechanisms. SFG Rickettsiae are believed to induce targeted focal membrane lysis for exit, allowing cell-to-cell spread without destruction of the host cell $[12,13]$. TG rickettsiae that miss an appropriate actin tail for directed movement [14, 15] grow in the cell until lysis or burst [13], and O. tsutsugamushi exits the cell by a budding-like process [16] (Fig. 1a). Free bacteria are then capable to infect adjacent cells. Local lesions of the blood vessels can lead to edema and thromboses. ECs in addition to tissue macrophages (MФ) release a series of cytokines, chemokines, and other mediators that lead to the recruitment and activation of immune cells that further promote local inflammatory responses. Figure $1 \mathrm{~b}$ provides an overview on local reactions in response to rickettsiae. Due to these reactions, the location of entry of several rickettsiae (SFG Rickettsiae, O. tsutsugamushi and $R$. prowazekii) is usually associated with an eschar. The 
Table 1 The family of Rickettsiaceae

\begin{tabular}{|c|c|c|c|c|c|c|}
\hline Genus & Group & Species & Vector & Reservoir & Disease/symptoms & Distribution \\
\hline \multirow[t]{16}{*}{ Rickettsia } & \multirow[t]{9}{*}{ SFG } & R. rickettsii & Tick & Rodents & Rocky Mountain SF & North, Central and South America \\
\hline & & R. conorii & Tick & Rodents & Mediterranean SF & Europe, Asia, Africa \\
\hline & & R. honei & Tick & Rodents & Flinder's island SF & Australia, Thailand \\
\hline & & R. japonica & Tick & Rodents & Japanese SF/oriental SF & Japan \\
\hline & & R. sibirica & Tick & Rodents & North Asian tick typhus & Russia, China, Mongolia, Europe \\
\hline & & R. africae & Tick & Rodents & African tick bite fever & Sub-Saharan Africa, Caribbean \\
\hline & & R. slovaca & Tick & Rodents & Necrosis, erythema & Europe \\
\hline & & R. helvetica & Tick & Rodents & Aneruptive fever & Africa, Europe, Asia \\
\hline & & R. parkeri & Tick & Rodents & Mild spotted fever & US, Brazil, Uruguay \\
\hline & \multirow[t]{2}{*}{ TG } & R. prowazekii & Louse & Human, flying squirrel & Epidemic typhus & Worldwide \\
\hline & & R. typhi & Flea & Rodents, cats, dogs & Endemic typhus & Worldwide \\
\hline & \multirow[t]{3}{*}{ Transitional } & R. felis & Flea & Rodents, cats, opossums & Cat flea typhus & Worldwide \\
\hline & & R. akari & Mite & Rodents & Rickettsialpox & Worldwide \\
\hline & & R. australis & Tick & Rodents & Queensland tick typhus & Australia, Tasmania \\
\hline & \multirow[t]{2}{*}{ Ancestral } & R. bellii & Tick & & & \\
\hline & & R. canadensis & Tick & & & \\
\hline Orientia & & O. tsutsugamushi & Mite & Rodents & Scrub typhus & Indian subcontinent, Asia, Australia \\
\hline
\end{tabular}

The family of Rickettsiceae consists of two genera: Rickettsia and Orientia. O. tsutsugamushi is the only member of the genus Orientia. The genus Rickettsia is subdivided into four groups: SFG (spotted fever group), TG (typhus group), transitional and ancestral rickettsiae. The vast majority of rickettsiae belongs to the SFG. SF spotted fever (adapted and modified from [5])

bacteria further spread via the blood stream and systemically distribute in the body during the course of disease, inducing inflammatory responses in the organs and in the skin where these reactions become visible as a characteristic spotted skin rash in $60-70 \%$ of the patients. Rickettsiae can enter nearly all tissues and organs. Apart from ECs they also infect monocytes/M $\mathrm{M}[3,6,17]$ and non-immune cells including hepatocytes [18, 19], smooth muscle cells [20], neurons [21] and fibroblasts that are commonly used for in vitro culture of rickettsiae [22-25]. Humans develop disease upon rickettsial infections within 10-14 days after inoculation. Common symptoms include fever, headache, myalgia, muscle aches, cough and rash. Severe complications such as pneumonia, heart and liver damage, nephritis, encephalitis or meningitis can occur and lead to a fatal outcome. The highest lethality $(20-30 \%)$ is observed in the infection with $R$. prowazekii [26-28].

Rickettsial infections are treated with antibiotics. A vaccine, however, is not available but highly desired for several reasons: (1) Rickettsial diseases are emerging worldwide with increasing incidence. (2) There is the risk of the development of antibiotic resistance. (3) The bacteria can persist despite antibiotic treatment. This is known for $R$. prowazekii [29], O. tsutsugamushi [30] $R$. rickettsii [31, 32] and quite likely for $R$. typhi [33]. R. prowazekii can be reactivated decades after primary infection and cause the so-called BrillZinsser disease [34-37]. Reactivation of persisting bacteria and recurrent disease may also occur in the infection with other rickettsiae. (4) Finally, rickettsiae are considered potential bioweapons.

\section{Murine models of rickettsial infections}

Vaccine development requires the understanding of immune mechanisms that are involved in protection and pathology. In recent years, immune response in rickettsial infections has been intensively studied in murine models of infection. Susceptible mouse strains reflect human disease in many aspects, including the development of vasculitis, pneumonia, hepatitis, meningoencephalitis and splenomegaly. $\mathrm{C} 3 \mathrm{H} / \mathrm{HeN}$ mice are susceptible to a broader range of rickettsiae while BALB/c and C57BL/6 mice that are commonly used to study immunity against infectious pathogens are resistant to most rickettsial infections. However, knockout mice from these strains that lack immune components provided much insight into immunity against rickettsial infections as described later. Table 2 provides an overview of murine models of rickettsial infections and the outcome of disease. 


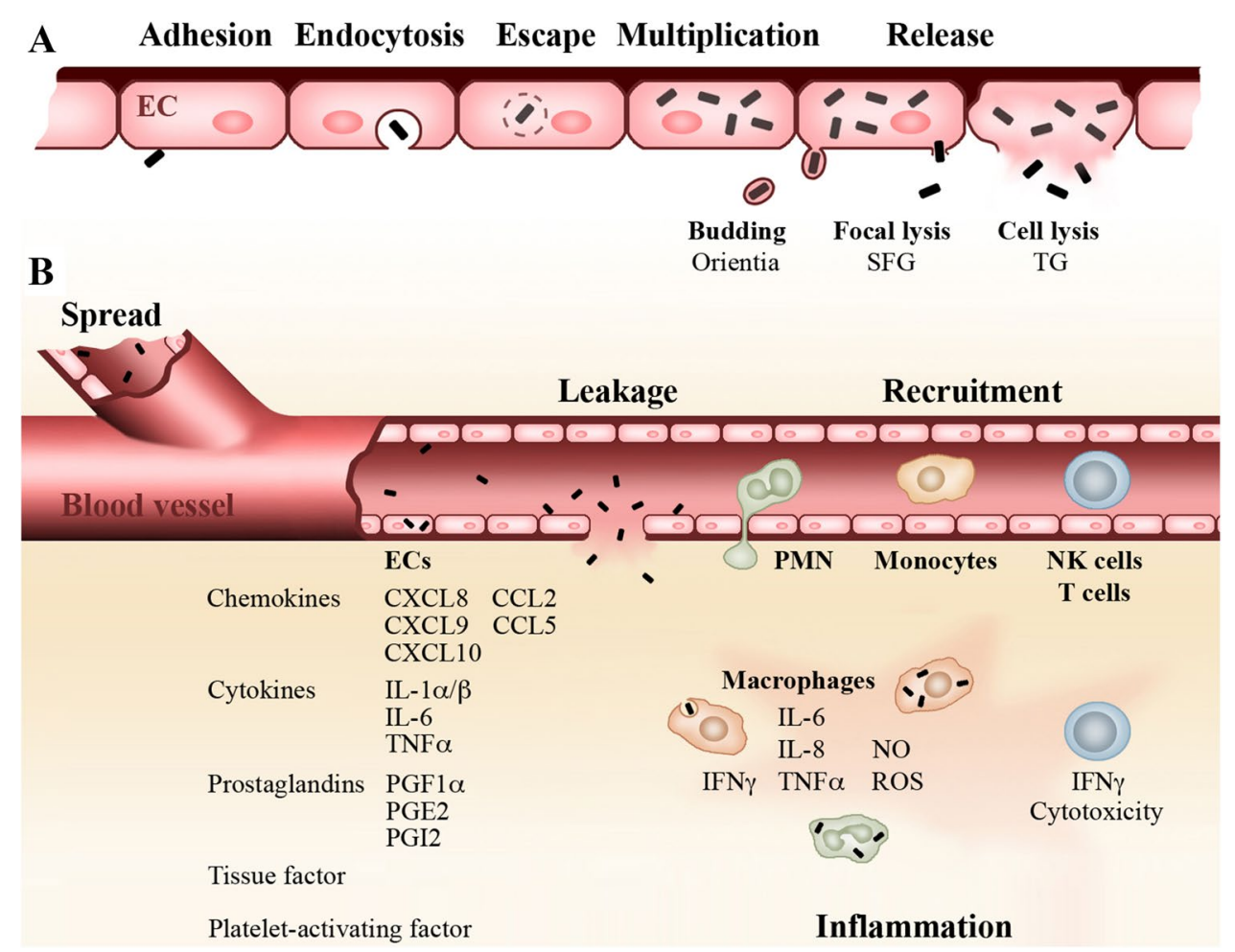

Fig. 1 Rickettsiae replicate in ECs and induce local inflammatory reactions. Rickettsiae enter ECs by endocytosis and rapidly escape from the endosome. The bacteria replicate free in the cytosol and are released by different mechanisms. SFG rickettsiae are capable to induce focal lysis while TG rickettsiae replicate in the cell until burst. O. tsutsugamushi induces a kind of budding (a). Rickettsiae infect adjacent ECs, further spread via the blood stream and enter the tissue via local lesions. Infected ECs release a series of chemokines,

\section{Immune response against rickettsiae}

\section{Response of non-immune target cells to rickettsial infections}

Although ECs are non-immune cells, once infected with rickettsiae they produce a series of mediators that contribute to the recruitment and activation of immune cells. Rickettsia-infected ECs release several chemokines that induce the recruitment and infiltration of immune cells from the periphery. These include CXCL8/IL-8, CCL2/ MCP-1 (monocyte chemoattractant protein 1) [54, 55], CXCL9/MIG (monokine-induced by gamma interferon), CXCL10/IP10 (interferon-gamma inducible protein 10) [56, 57] and CCL5/RANTES [57]. CXCL8/IL-8 predominantly recruits neutrophils to the site of infection via CXCR1 and 2 [58-60]. It activates exocytosis and the production of bactericidal reactive oxygen species (ROS) in neutrophils [58] and in this way acts pro-inflammatory. CXCL8/IL-8 further has anti-apoptotic effects on ECs, promotes endothelial proliferation and angiogenesis cytokines, prostaglandins and other factors. Chemokines attract neutrophils, monocytes/M $\mathrm{M}, \mathrm{NK}$ cells and $\mathrm{T}$ cells from the periphery into the affected tissue. МФ and neutrophils both of which also get infected with rickettsiae release NO and ROS which is important for killing of ingested bacteria. The production of NO is supported by IFN $\gamma$ which is provided by infiltrating NK cells and T cells. MФ and infiltrating NK and $\mathrm{T}$ cells further produce inflammatory cytokines such as TNF $\alpha$ that contribute to local inflammation (b)

[61]. CCL2/MCP-1 and CCL5/RANTES are involved in the recruitment of monocytes and other leukocytes that express CCR1, 2, 3 or $5[62,63]$ while CXCL9 and CXCL10 attract activated NK and T cells, predominantly $\mathrm{CD} 4^{+} \mathrm{T}_{\mathrm{H}} 1$ cells and $\mathrm{CD} 8^{+}$cytotoxic $\mathrm{T}$ cells, via CXCR3 [64]. ECs further upregulate the expression of adhesion molecules such as E-selectin which facilitates neutrophil adhesion [65] and ICAM-1 [66], promoting the adhesion and transmigration of activated leukocytes [67].

ECs activate infiltrating immune cells by the release of inflammatory cytokines including IL- $1 \beta$, IL- 6 and TNF $\alpha$ $[57,68]$. IL- $1 \beta$ activates similar responses in innate immune cells as the recognition of pathogens via Toll-like receptors (TLR) [69]. IL-6 drives the differentiation of infiltrating monocytes to $\mathrm{M} \Phi$, enhances the production of CCL2/ MCP-1, CCL8/MCP-2, CXCL5/ENA-78 and CXCL6/ GCP-2 in tissue cells, the expression of ICAM-1, VCAM-1 and E-selectin on ECs as well as L-selectin on lymphocytes [70]. In this way IL-6 enhances leukocyte transmigration.

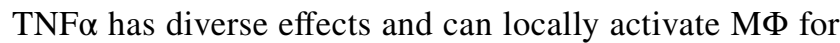
bacterial killing [71]. 
Table 2 Murine models of rickettsial infections

\begin{tabular}{|c|c|c|c|c|c|c|}
\hline Strain & Species & Route & Suscept. & Pathology & Persistence & References \\
\hline \multicolumn{7}{|l|}{ BALB/c } \\
\hline \multirow[t]{4}{*}{ Wild-type } & R. australis & i.v. & ++ & Vasculitis, pneumonia, hepatitis & & {$[38]$} \\
\hline & R. akari & i.p. & - & & & [39] \\
\hline & R. typhi & s.c., i.v. & - & Pneumonia, hepatitis (mild) & yes & {$[33,40]+$ Osterloh unpubl. } \\
\hline & O. tsutsugamushi & s.c., i.p. & - & $\begin{array}{l}\text { Pneumonia, hepatits, myocarditis, } \\
\text { meningoencephalitis }\end{array}$ & yes & {$[41-43]$} \\
\hline CB17 & $R$. conorii & i.v. & - & Mild hepatitis & & {$[44]$} \\
\hline \multirow[t]{2}{*}{ CB17 SCID } & R. conorii & i.v. & - & Mild hepatitis & & [44] \\
\hline & R. typhi & s.c. & ++++ & $\begin{array}{l}\text { Strong hepatitis, splenomegaly, sys- } \\
\text { temic inflammation (IFN } \gamma \text { ) }\end{array}$ & & {$[40,45]$} \\
\hline $\mathrm{RAG}^{-/-}$ & R. typhi & s.c. & ++++ & $\begin{array}{l}\text { Strong hepatitis, splenomegaly, sys- } \\
\text { temic inflammation (IFN } \gamma \text { ) }\end{array}$ & & {$[45]$} \\
\hline $\mathrm{IFN} \gamma^{-1-}$ & R. typhi & s.c. & - & & & {$[45]$} \\
\hline Perforin $^{-/-}$ & R. typhi & s.c. & - & & & [45] \\
\hline \multicolumn{7}{|l|}{ C57BL/6 } \\
\hline \multirow[t]{5}{*}{ Wild-type } & R. australis & i.v. & + & & & {$[46]$} \\
\hline & R. akari & i.p. & - & & & [39] \\
\hline & R. conorii & i.v. & - & & & [46] \\
\hline & R. typhi & s.c., i.v. & - & Mild hepatitis, pneumonia & yes & {$[33,47]+$ Osterloh unpubl. } \\
\hline & O. tsutsugamushi & i.p. & - & & & {$[43]$} \\
\hline \multirow[t]{2}{*}{$\mathrm{MHCI}^{-/-}$} & R. australis & i.v. & +++ & Encephalitis & & [46] \\
\hline & R. typhi & s.c. & - & & & [47] \\
\hline $\mathrm{MHCII}^{-/-}$ & R. typhi & s.c. & - & & & [47] \\
\hline $\mathrm{RAG}^{-/-}$ & R. conorii & i.v. & $-(?)$ & $\begin{array}{l}\text { Survival for at least } 21 \text { days, mild } \\
\text { hepatitis }\end{array}$ & & {$[44,46]$} \\
\hline $\mathrm{RAG}^{-/-}$ & R. typhi & s.c., i.v. & ++++ & $\begin{array}{l}\text { Survival for }>3 \text { months, lethal CNS } \\
\text { inflammation }\end{array}$ & yes & {$[33]$} \\
\hline $\mathrm{RAG}^{-/-} \gamma \mathrm{c}^{-/-}$ & R. conorii & i.v. & ++ & Enhanced hepatitis & & {$[44]$} \\
\hline RAG2 $^{-l-}$ Perforin ${ }^{-1-}$ & R. conorii & i.v. & + & & & [44] \\
\hline Perforin $^{-/-}$ & R. australis & i.v. & +++ & & & {$[44,46]$} \\
\hline $\mathrm{IFN} \gamma^{-} /^{-}$ & R. australis & i.v. & ++ & & & {$[46]$} \\
\hline $\mathrm{NLRP}^{-/-}$ & R. australis & i.v. & ++ & & & [48] \\
\hline \multicolumn{7}{|l|}{$\mathrm{C} 3 \mathrm{H} / \mathrm{HeN}$} \\
\hline \multirow[t]{5}{*}{ Wild-type } & R. akari & i.p. & - & & & [39] \\
\hline & R. conorii & i.v. & ++ & $\begin{array}{l}\text { Meningoencephalitis, pneumonia, } \\
\text { hepatitis }\end{array}$ & & {$[18,44]$} \\
\hline & R. typhi & i.v. & + & Encephalitis, pneumonia & & [49] \\
\hline & O. tsutsugamushi & i.p. & ++ & & & [43] \\
\hline & R. parkeri & i.v. & - & & & {$[50]$} \\
\hline \multirow[t]{5}{*}{$\mathrm{C} 3 \mathrm{H} / \mathrm{HeJ}$} & R. australis & i.p. & - & & & {$[51]$} \\
\hline & R. akari & i.p. & + & & & [39] \\
\hline & R. conorii & i.v. & +++ & & & {$[52]$} \\
\hline & R. rickettsii & i.p & - & & & {$[51]$} \\
\hline & R. sibirica & i.p. & ++ & & & {$[51]$} \\
\hline
\end{tabular}


Table 2 (continued)

\begin{tabular}{|c|c|c|c|c|c|c|}
\hline Strain & Species & Route & Suscept. & Pathology & Persistence & References \\
\hline & R. parkeri & i.v & +++ & Splenomegaly & & [50] \\
\hline C3H/HeN SCID & R. conorii & i.v.. & ++++ & & & [53] \\
\hline
\end{tabular}

In recent years immune response against rickettsiae has been intensively studied in murine models of infection. BALB/c and C57BL/6 mice that are commonly used for the study of immunity against infectious pathogens are resistant against most rickettsiae while $\mathrm{C} 3 \mathrm{H} / \mathrm{HeN}$ mice are susceptible to a broader range of rickettsiae. Except for $\mathrm{C} 3 \mathrm{H} / \mathrm{HeJ}$ mice that are deficient in the expression of a functional TLR4 receptor, knockout mice on the $\mathrm{C} 3 \mathrm{H}$ background are not available. Much knowledge about protective immunity against rickettsial infections has been gained from the comparison of rickettsial infections in BALB/c and C57BL/6 wild-type mice and mice of these backgrounds that either lack components of adaptive immunity or effector molecules such as IFN $\gamma$ and Perforin. Overall, the enhanced susceptibility of BALB/c or C57BL/6 mice that either lack $\mathrm{T}$ and $\mathrm{B}$ cells (CB17 SCID, RAG2 ${ }^{-/-}$and $\mathrm{RAG}^{-/-}$mice), $\mathrm{CD}^{+} \mathrm{T}$ cells $\left(\mathrm{MHCI}^{-1-}\right.$ ) or $\mathrm{CD}^{+} \mathrm{T}$ cells $\left(\mathrm{MHCII}^{-/-}\right.$) to rickettsial infections demonstrates the importance of adaptive immunity, especially of $\mathrm{T}$ cells, in defense against these pathogens

Suscept. susceptibility; i.v. intravenous; i.p. intraperitoneal; s.c. subcutaneous

Finally, rickettsia-infected ECs produce prostaglandins including the vasoactive prostaglandins PGF1 $\alpha$, PGI 2 and PGE2 [72, 73], PAF (platelet-activating factor), a mediator of platelet aggregation, degranulation and vascular permeability [74], and TF (tissue factor) [75] which is induced by IL-1 $\beta$ in an autocrine manner [68]. TF is an integral membrane protein that interacts with plasma factor VII when expressed on damaged ECs and initiates blood coagulation [76]. The transcription factor NF- $\kappa B$ that gets activated in rickettsia-infected ECs [77] has been demonstrated to be involved in many of these events including the expression of TF [78], CXCL8, und CCL2 [54]. In addition, NF-кB acts as an anti-apoptotic factor for rickettsia-infected ECs [79].

\section{Role of innate immune cells in protection and pathology}

\section{Phagocytes}

Apart from a series of non-immune cells also cells of the innate immune system, especially phagocytes such as $M \Phi$, that are recruited to the location of infection can get infected by rickettsiae. Various rickettsiae infect primary $\mathrm{M} \Phi$ as well as $M \Phi$ cell lines in vitro and replicate within these cells. In fact, some rickettsiae seem to predominantly infect $\mathrm{M} \Phi$ rather than ECs. This is postulated for R. akari [80] and may be also true for $O$. tsutsugamushi, R. conorii and R. typhi. $O$. tsutsugamushi is found predominantly in $\mathrm{M} \Phi$ in the tissues of infected BALB/c mice [41], and both O. tsutsugamushi and $R$. conorii are detectable in hepatic $\mathrm{M} \Phi$, most likely Kupffer cells, in the liver of infected mice [18, 81]. R. typhi is exclusively detectable in $\mathrm{M} \Phi$, but not in ECs, in CB17 SCID and C57BL/6 RAG1 ${ }^{-/-}$mice with advanced infection $[33,40]$.

The activation of M $\Phi$ upon infection depends on the rickettsial species. $R$. australis induces the release of IL-1 $\beta$ and IL-18 in bone marrow-derived M $\Phi$ from BALB/c mice [48]. R. australis-infected C57BL/6 and BALB/c mice show enhanced serum levels of IL-1 $\beta$, IL-6, IL-12p40 and TNF $\alpha$
$[38,82]$. Correspondingly, serum levels of IL-6 and IL-12 are increased in $\mathrm{C} 3 \mathrm{H} / \mathrm{HeN}$ mice upon $R$. conorii infection [52]. These cytokines are typically produced by MФ.R. australis further activates Caspase-1 as well as the inflammasome in bone marrow-derived M $\Phi$ from BALB/c mice [48]. The latter seems to play a role in the control of this pathogen because $R$. australis-infected C57BL/6 NLRP $3^{-1-}$ mice that are deficient in the formation of the inflammasome show enhanced bacterial burden in the spleen, although not in other organs [48]. $R$. akari induces the activation of NF- $\mathrm{kB}$ and the expression of IL-1 $\beta$, IL- 6 and TNF $\alpha$ in P338D1 M $\Phi$ and peritoneal $\mathrm{M} \Phi$ from $\mathrm{C} 3 \mathrm{H} / \mathrm{HeN}$ mice [17]. The same has been observed upon the infection of peritoneal M $\Phi$ from $\mathrm{C} 3 \mathrm{H} / \mathrm{HeN}$ mice with $R$. typhi that additionally induced the release of TGF $\beta$ [17]. In other studies, however, bone marrow-derived M $\Phi$ from BALB/c and C57BL/6 mice neither produced cytokines nor nitric oxide (NO) upon infection with $R$. typhi, but exclusively upregulated MHCI and CD80 on the cell surface $[40,47]$. Although there may be differences in the reactivity of $M \Phi$ from different mouse strains and also between peritoneal and bone marrow-derived $M \Phi$, these observations argue against classical activation of $M \Phi$ by $R$. typh $i$ which is usually mediated by pathogen recognition via pathogen recognition receptors such as TLR.

These receptors typically activate the transcription factor NF- $\mathrm{KB}$ which induces the release of several inflammatory cytokines (IL-6, IL-12, TNF $\alpha$ ), the expression of inducible nitric oxide synthase (iNOS) which produces NO, the upregulation of MHC class I and II and costimulatory CD80 and CD86 molecules [83]. TLR4 and TLR2 seem to be engaged in the activation of innate immune response. For example, $R$. akari activates NF- $\mathrm{\kappa B}$ in reporter cell lines via TLR4 and also TLR2 [84]. TLR4 has also been implicated in protection against rickettsiae in vivo. $\mathrm{C} 3 \mathrm{H} / \mathrm{HeJ}$ mice that lack a functional TLR4 show enhanced susceptibility to $R$. conorii and develop overwhelming bacterial burden and fatal disease when infected with a normally sublethal dose [52]. Similar observations were also made for the infection 
of $\mathrm{C} 3 \mathrm{H} / \mathrm{HeJ}$ mice with $R$. parkeri [50]. An important role of TLR in defense against rickettsiae is further supported by the finding that $\mathrm{C} 57 \mathrm{BL} / 6 \mathrm{MyD} 88^{-/-}$mice that lack the conserved MyD88 signaling pathway which is common to TLRs [83] succumb to the infection with $R$. conorii as well as with $R$. australis [82]. In addition, $R$. australis-infected C57BL/6 MyD88 ${ }^{-1-}$ show reduced serum levels of IL-6, $\mathrm{IL}-12 \mathrm{p} 40, \mathrm{TNF} \alpha$ and also IFN $\gamma$ compared to wild-type mice [82] which is also true for $R$. conorii-infected $\mathrm{C} 3 \mathrm{H} / \mathrm{HeJ}$ mice that produce reduced serum levels of IL-6 and IL-12 and show enhanced numbers of regulatory $\mathrm{T}$ cells compared to $\mathrm{C} 3 \mathrm{H} / \mathrm{HeN}$ wild-type mice [52]. These findings indicate missing innate immune activation by these rickettsial species in the absence of TLR4 which is essential for the initiation of protective adaptive immunity.

The role of TLR in protection against $O$. tsutsugamushi and also TG rickettsiae, however, is not clear. In the infection with $O$. tsutsugamushi TLR2, but not TLR4, is required for the release of TNF $\alpha$ and IL-6 by dendritic cells (DCs) upon pathogen contact [85]. C57BL/6 TLR2 ${ }^{-1-}$ mice, however, are more resistant to lethal infection with $O$. tsutsugamushi compared to C57BL/6 wild-type mice [85]. Although C57BL/6 TLR2 ${ }^{-1-}$ mice develop a higher bacterial burden compared to C57BL/6 wild-type mice in the infection with O. tsutsugamushi, C57BL/6 $\mathrm{TLR}^{-/-}$mice show milder symptoms of disease and enhanced survival rates [85]. These findings show that the activation of innate immunity via TLR2 although being involved in bacterial elimination in this infection clearly has pathological effects that are largely responsible for disease.

Immunopathology mediated by innate immune mechanisms is also responsible for the lethal outcome of the infection of CB17 SCID mice and C57BL/6 $\mathrm{RAG}^{-1-}$ mice with $R$. typhi. CB17 SCID mice succumb to the infection with $R$. typhi within 3 weeks, develop splenomegaly due to the massive expansion of $\mathrm{M} \Phi$ and neutrophils, and severe liver necrosis [40]. Liver damage in these mice is exclusively mediated by the action of infiltrating neutrophils [40]. Neutrophils and $M \Phi$ express iNOS, release reactive oxygen species (ROS) and TNF $\alpha$ in the infection with $R$. typhi [40], and death of the animals can be ascribed to overwhelming systemic release of inflammatory cytokines [40]. Systemic inflammation is clearly dominated by the production of IFN $\gamma$ for which NK cells as well as M $\Phi$ are the major source in $R$. typhi-infected CB17 SCID mice [40]. In contrast to CB 17 SCID mice, C57BL/6 $\mathrm{RAG}^{-/-}$mice can control $R$. typhi for 3-4 months before the bacteria start to grow predominantly in the brain [33]. This leads to fatal inflammation of the central nervous system (CNS) which is associated with the infiltration of activated $M \Phi$ from the periphery and the expansion and activation of microglia. In the CNS of these mice, R. typhi is almost exclusively found in infiltrating $\mathrm{M} \Phi$ [33], and the same is also true for $R$. typhi-infected CB17 SCID mice where the bacteria reside in $M \Phi$ and neutrophils [40]. How these cells get activated in the infection of CB17 SCID and C57BL/6 RAG1 ${ }^{-/-}$mice, however, is unclear. The majority of activated M $\Phi$ and neutrophils that express iNOS in $R$. typhi-infected mice does not harbor the bacteria [40]. Together with the finding that $R$. typhi does not activate bone marrow-derived M $\Phi$ from BALB/c and C57BL/6 mice in vitro in a classical manner [40, 47], a role of TLR in the activation of innate immune response by TG rickettsiae such as $R$. typhi is questioned. It has been suggested that activation of M $\Phi$ in the infection with $R$. typhi in vivo is mediated by indirect mechanisms such as the release of endogenous danger signals by damaged cells rather than direct recognition of the bacteria [40].

Although $M \Phi$ react to the infection with rickettsiae, they are incapable of killing the ingested bacteria without help and the bacteria replicate within these cells in vitro. In addition, some rickettsiae such as $O$. tsutsugamushi, $R$. typhi, $R$. conorii and $R$. parkeri seem to predominantly infect $M \Phi$ in vivo [18, 33, 40, 80, 81]. Therefore, it is speculated that some rickettsiae may use $\mathrm{M} \Phi$ as a vehicle for transport through the body. Such "shuttle" service is discussed for $O$. tsutsugamushi [86] as well as for R. typhi [33].

Bacterial killing by $M \Phi$ and also other cells can be induced by cytokines. Important cytokines that can activate the bactericidal activity of M $\Phi$ are IFN $\gamma$ and TNF $\alpha$. IFN $\gamma$ induces the expression of iNOS and subsequent release of NO by M $\Phi$ and also endothelial cells [87-89]. TNF $\alpha$ also induces the expression of iNOS in M $\Phi$ [87] and synergizes with IFN $\gamma$ in this effect [71]. IFN $\gamma$ has been shown to inhibit the growth of $R$. prowazekii in murine and human fibroblasts [90], and IFN $\gamma$ as well as TNF $\alpha$ inhibit the growth of $R$. typhi in murine MФ in vitro [45]. IFN $\gamma$ and TNF $\alpha$ as well as IL-1 $\beta$ and RANTES also activate bacterial killing of $R$. conorii in human THP1 M $\Phi, \mathrm{AKN}-1$ hepatocytes and HUVEC ECs via NO-dependent mechanisms [91].

\section{Natural killer (NK) cells}

Natural killer cells are innate cytotoxic cells that are capable of direct killing of infected target cells and have been implicated in early innate defense against rickettsial infections. Enhanced NK cell activity has been reported early in infection on days $2-6$ in $R$. conorii-infected $\mathrm{C} 3 \mathrm{H} / \mathrm{HeN}$ mice [92]. At the same time $\mathrm{C} 3 \mathrm{H} / \mathrm{HeN}$ mice show enhanced serum levels of IFN $\gamma$ early in the infection with $R$. conorii which could be ascribed to NK cells. IFN $\gamma$ serum levels were significantly reduced upon NK cell depletion by antibody, and the mice showed enhanced susceptibility to the infection with $R$. conorii [92]. Furthermore, C57BL/6 mice 
that are resistant to rickettsial infections show enhanced NK cell activity and IFN $\gamma$ production early in the infection with $R$. conorii compared to susceptible $\mathrm{C} 3 \mathrm{H} / \mathrm{HeN}$ mice [44]. Moreover, C57BL/6 RAG2 ${ }^{-1-} \gamma^{-1-}$ mice that lack not only $\mathrm{T}$ and $\mathrm{B}$ cells but also NK cells [93] produce reduced serum levels of IFN $\gamma$ and develop enhanced bacterial burden and liver pathology in the infection with $R$. conorii compared to NK cell-competent C57BL/6 RAG2 ${ }^{-1-}$ mice [44]. Similarly, NK cell-depleted CB17 SCID mice show enhanced susceptibility to the infection with $R$. conorii compared to CB 17 mice [44]. These findings indicate an important role of NK cells and NK cell-derived IFN $\gamma$ in early rickettsial defense which seems to be mainly mediated via the production of IFN $\gamma$ rather than the cytotoxic activity because $R$. conoriiinfected C57BL/6 RAG2 ${ }^{-1-}$ Perforin $^{-1-}$ mice produce higher levels of IFN $\gamma$ and have lower bacterial burden compared to C57BL/6 RAG1 ${ }^{-1-}$ mice [44]. R. conorii-infected C57BL/6 $\mathrm{RAG}^{-/}{ }^{-}$Perforin $^{-1-}$ mice, however, develop enhanced liver pathology despite reduced bacterial burden [44], indicating immunopathology rather than direct cellular damage by the bacteria.

Enhanced NK cell activity has also been reported early in the infection with $R$. typhi on day 2 in C57BL/6 mice [92], and NK cells have been implicated in early defense against $R$. typhi in mice [94]. For example, enhanced bacterial burden was observed in $R$. typhi-infected C57BL/6 mice upon NK cell depletion [92]. The contribution of NK cells to the control of $R$. typhi, however, is not that clear. NK cells did not significantly expand in the initial phase of infection (30 days) in $R$. typhi-infected C57BL/6 RAG1 ${ }^{-/-}$mice, and the animals did not show any signs of disease upon depletion of NK cells during this time [33]. R. typhi-infected C57BL/6 RAG1 ${ }^{-1-}$ mice further developed neurological disease with similar kinetics as control animals 3 months post infection [33]. In addition, although enhanced serum levels of IFN $\gamma$ were observed in $R$. typhi-infected C57BL/6 $\mathrm{RAG}^{-/-}$mice on day 3 post infection, IFN $\gamma$ release was unaltered upon NK cell depletion [33], demonstrating that early IFN $\gamma$ in these mice does not predominantly derive from NK cells but other cells, e.g. M $\Phi$ and innate lymphoid cells. Only moderate increase of NK cells was also observed in $R$. typhi-infected CB17 SCID mice, and the high amounts of IFN $\gamma$ that are detectable in these mice equally derive from NK cells and M $\Phi$ [40]. Despite the activation of NK cells and M $\Phi$ in the infection, CB17 SCID mice are incapable to control the bacteria and develop high bacterial burden, predominantly in the spleen [40]. Together with the findings in $R$. typhi-infected C57BL/6 RAG1 ${ }^{-1-}$ mice, these observations question an important role of NK cells in defense against TG rickettsiae and demonstrate that protective cytokines such as IFN $\gamma$ and TNF $\alpha$ have to be locally provided by cells of the adaptive immune system to act protective.

\section{Adaptive immune response to rickettsial infections}

\section{$B$ cells and the role of antibodies in protection against rickettsiae}

Adaptive immunity is essential for protection against rickettsiae. This is clearly reflected by the observation that Tand $\mathrm{B}$ cell-deficient mice are highly susceptible to rickettsial infections [33, 40, 53]. B cells can contribute to protection by the production of antibodies. Here, it seems that antibodies that are produced in the absence of $\mathrm{CD}^{+} \mathrm{T}$ cell help as it is the case in the early phase of infection are less protective than antibodies generated with $\mathrm{T}$ cell help. This has been demonstrated in the infection of athymic BALB $/ \mathrm{c}^{\text {nude/ }}$ nude mice that do not possess mature and functional $\mathrm{T}$ cells with $R$. akari. $\mathrm{BALB} / \mathrm{c}^{\text {nude/nude }}$ mice infected with $R$. akari and treated with antibiotics to terminate the infection developed antibodies but were not protected against reinfection with $R$. akari [95]. On the other hand, antibodies produced by athymic mice after immunization with heat-killed $R$. akari protected euthymic $\mathrm{BALB} / \mathrm{c}^{\text {nude/+ }}$ mice against challenge with $R$. akari, whereas antibodies from immunized euthymic mice failed to protect $\mathrm{BALB} / \mathrm{c}^{\text {nude/nude }}$ mice against this pathogen [95]. These findings indicate protective effects of $\mathrm{T}$ cell-independent antibodies and suggest a minor role of $\mathrm{T}$ cell-dependent antibodies in primary infection. In another study, however, passive immunization with polyclonal immune serum as well as with monoclonal antibodies against outer membrane proteins $\mathrm{A}(\mathrm{OmpA})$ or B (OmpB), but not lipopolysaccharide (LPS), protected C3H/HeN SCID mice from challenge with $R$. conorii [53]. Moreover, the application of polyclonal immune serum even prolonged the survival of $\mathrm{C} 3 \mathrm{H} / \mathrm{HeN}$ SCID mice with already established $R$. conorii infection and led to reduced bacterial burden [53], demonstrating protective effects.

The protective function of the antibodies depends on the Fc part because Fab fragments of the antibodies were not protective in this model [53]. Antibodies can mediate protection by different mechanisms: (1) the opsonization of particles for the uptake by phagocytes, (2) binding to the pathogen surface and activation of complement which directly attacks the pathogen, or (3) the inhibition of infection via the blockade of molecules that are involved in binding to surface receptors and bacterial uptake. Opsonization of rickettsial particles seems to be at least one mechanism by which antibodies can contribute to protection. Opsonization of $R$. conorii with polyclonal or monoclonal anti-OmpA and anti-OmpB antibodies resulted in enhanced uptake of the bacteria into endothelial cells (SVEC 4-10) and M $\Phi$-like cells (J774A.1) and inhibited bacterial growth in vitro [96]. Polyclonal antibodies and monoclonal anti-OmpB inhibited the phagosomal escape of $R$. conorii, and killing of the bacteria could be ascribed to the release of NO, ROS and 
L-tryptophan starvation [96]. In passively immunized mice, intraphagosomal killing of $R$. conorii in $\mathrm{M} \Phi$ and the accumulation of $R$. conorii antigen in these cells was observed [53].

While antibodies against LPS can be detected already on day 6 after the infection of $\mathrm{C} 3 \mathrm{H} / \mathrm{HeN}$ mice with $R$. conorii [53], specific antibodies that are generated with the help of $\mathrm{CD} 4^{+} \mathrm{T}$ cells appear relatively late in rickettsial infections. For example, antibodies against OmpA and OmpB become detectable as late as on day 12 when $R$. conorii-infected $\mathrm{C} 3 \mathrm{H} / \mathrm{HeN}$ mice already have recovered [53], and the same is also true for humans. $R$. typhi-infected patients develop a diagnostic antibody titer as late as 15 days after the onset of symptoms [97], and seroconversion in $R$. conorii and $R$. africae infection occurs even later between day 16 and 25 [98]. Overall, the role of antibodies in protection against rickettsial infections is not that clear. It is assumed that antibodies do not play a major role in defense in primary infection but may contribute to protection in secondary infection.

\section{Mechanisms of $\mathbf{T}$ cell-mediated protection against rickettsial infections}

$\mathrm{T}$ cells clearly play a dominant role in defense against rickettsial infections. Apart from providing help in antibody production by $\mathrm{B}$ cells, the probably more important role of $\mathrm{CD}^{+} \mathrm{T}$ cells lies within their capacity to release effector molecules. $\mathrm{CD} 8^{+} \mathrm{T}$ cells, on the other hand, are cytotoxic cells that can directly kill infected cells. In recent years, effector mechanisms that are involved in T cell-mediated protection against rickettsial infections have been studied in more detail. In the following, the current knowledge of the mechanisms of $\mathrm{CD} 8^{+}$and $\mathrm{CD} 4^{+} \mathrm{T}$ cell-mediated protection is discussed.

\section{$\mathrm{CD8}^{+} \mathrm{T}$ cells}

$\mathrm{CD}^{+} \mathrm{T}$ cells are activated during rickettsial infections and protective against rickettsial infections without doubt. $\mathrm{CD}^{+}$ T cells from $R$. conorii-infected $\mathrm{C} 3 \mathrm{H} / \mathrm{HeN}$ and $R$. australisinfected C57BL/6 mice show enhanced cytotoxic activity ex vivo against $R$. conorii-infected ECs or J774A.1 M $\Phi$-like cells [46]. The peak response is observed on day 10 post infection [46]. Similarly, $\mathrm{CD} 8^{+} \mathrm{T}$ cells from $R$. typhi-infected C57BL/6 [47] and BALB/c mice [45] express enhanced levels of Granzyme B, demonstrating cytotoxic properties, and release IFN $\gamma$. Both Granzyme B and IFN $\gamma$ expression peak on day 7 post infection in both strains of mice [45, 47]. Interestingly, in $R$. typhi-infected C57BL/6 mice a low level of activated $\mathrm{CD} 8^{+} \mathrm{T}$ cells persists [47], and in $\mathrm{BALB} / \mathrm{c}$ mice even periodic reactivation of $\mathrm{CD} 8^{+} \mathrm{T}$ cells occurs [45]. As it has been recently shown that $R$. typhi persists in both mouse strains [33], a long-lasting $\mathrm{CD} 8^{+} \mathrm{T}$ cell response as well as
$\mathrm{CD}^{+}{ }^{+} \mathrm{T}$ cell response seems to be important for the control of persisting bacteria. In $\mathrm{C} 3 \mathrm{H} / \mathrm{HeN}$ mice $\mathrm{CD} 8^{+} \mathrm{T}$ cells are essential for the protection against rickettsial infections. Depletion of $\mathrm{CD}^{+} \mathrm{T}$ cells leads to enhanced susceptibility of $\mathrm{C} 3 \mathrm{H} / \mathrm{HeN}$ mice to $R$. conorii $[46,99]$ as well as to $R$. typhi [49]. In the absence of $\mathrm{CD} 8^{+} \mathrm{T}$ cells, infected $\mathrm{C} 3 \mathrm{H} /$ $\mathrm{HeN}$ mice show enhanced bacterial burden and pathology. Furthermore, C57BL/6 $\mathrm{MHCI}^{-1-}$ mice that lack CD ${ }^{+} \mathrm{T}$ cells are higly susceptible to a lethal outcome in the infection with $R$. australis compared to wild-type mice [46]. Finally, adoptive transfer of $\mathrm{CD} 8^{+} \mathrm{T}$ cells from immune mice protects $\mathrm{C} 3 \mathrm{H} / \mathrm{HeN}$ mice against challenge with a normally lethal dose of $R$. conorii [99] and C57BL/6 $\mathrm{RAG}^{-/-}$mice against lethal infection with $R$. typhi, even when transferred into mice with already established infection [47]. In $R$. typhiinfected C57BL/6 RAG1 ${ }^{-/-}$mice, adoptively transferred $\mathrm{CD}^{+} \mathrm{T}$ cells enter the brain which is the organ with the highest bacterial burden in these animals and quickly eliminate the bacteria. Moreover, the mice do not develop clinical symptoms [47]. Similarly, CB17 SCID mice substituted with $\mathrm{CD}^{+} \mathrm{T}$ cells are resistant to the infection with $R$. typhi and remain asymptomatic [45]. In contrast to the infection with R. australis, however, $\mathrm{CD} 8^{+} \mathrm{T}$ cells are sufficient but not essential for protection in the infection with $R$. typhi. Both $\mathrm{C} 57 \mathrm{BL} / 6 \mathrm{MHCI}^{-1-}$ as well as $\mathrm{C} 57 \mathrm{BL} / 6 \mathrm{MHCII}^{-/-}$mice, that either lack $\mathrm{CD} 8^{+}$or $\mathrm{CD} 4^{+} \mathrm{T}$ cells are equally resistant to $R$. typhi, do not show signs of disease and survive the infection [47].

Because rickettsiae are intracellular pathogens, especially the cytotoxic activity of $\mathrm{CD} 8^{+} \mathrm{T}$ cells has long been considered the most important mechanism of defense. C57BL/6 Perforin $^{-/-}$mice that lack the cytotoxic potential show a higher susceptibility and lethality upon infection with $R$. australis compared to $\mathrm{C} 57 \mathrm{BL} / 6 \mathrm{IFN} \gamma^{-1-}$ mice, although being much less susceptible than $\mathrm{C} 57 \mathrm{BL} / 6 \mathrm{MHCI}^{-1-}$ that lack $\mathrm{CD}^{+} \mathrm{T}$ cells at all [46]. This indicates a higher contribution of cytoxicity to recovery compared to the release of IFN $\gamma$. In fact, the release of IFN $\gamma$ by $\mathrm{CD}^{+} \mathrm{T}$ cells was dispensable for defense against this infection because immune $\mathrm{CD} 8^{+} \mathrm{IFN} \gamma^{-/-} \mathrm{T}$ cells adoptively transferred into $R$. australis-infected C57BL/6 IFN $\gamma^{-1-}$ mice reduced the bacterial load and conferred protection [46].

In contrast to the infection of mice on the C57BL/6 background with $R$. australis, BALB/c Perforin ${ }^{-/-}$mice and $\mathrm{BALB} / \mathrm{c} \mathrm{IFN} \gamma^{-1-}$ mice are as resistant to the infection with R. typhi as wild-type mice [45]. Moreover, CB17 SCID mice infected with this pathogen and substituted with either $\mathrm{CD} 8^{+}$ from BALB/c IFN $\gamma^{-1-}$ or BALB/c Perforin ${ }^{-1-}$ mice survived the infection without showing symptoms of disease at any point in time [45]. Thus, the cytotoxic activity of $\mathrm{CD} 8^{+}$ $\mathrm{T}$ cells is not essential for protection in the infection with $R$. typhi. In the study mentioned above, $R$. typhi-infected $\mathrm{CD} 8^{+} \mathrm{T}$ cell recipient mice were followed for more than 
120 days and then analyzed for the presence of persisting bacteria. Surprisingly, the bacteria were not detectable at all in the organs of $\mathrm{CD} 8^{+}$Perforin $^{-1-} \mathrm{T}$ cell recipient mice, while CB17 SCID mice that received $\mathrm{CD} 8^{+} \mathrm{T}$ cells from IFN $\gamma^{-1-}$ mice had bacteria predominantly in the brain and to a much lesser extent in the spleen, lung and liver. None of the animals, however, showed signs of disease [45]. These results indicate that $\mathrm{CD}^{+} \mathrm{T}$ cell-derived IFN $\gamma$ may be even more important than the cytotoxic activity in defense against $R$. typhi, at least in the control of persisting bacteria. They also indicate that persisting $R$. typhi may reside in the brain which is an immune privileged organ.

Overall, it has become clear that the cytotoxic activity as well as the release of IFN $\gamma$ by $\mathrm{CD} 8^{+} \mathrm{T}$ cells is important for protection against rickettsial infections. In case of $R$. typhi both either the cytotoxic activity or the release of IFN $\gamma$ by $\mathrm{CD} 8^{+} \mathrm{T}$ cells is sufficient for protection while cytotoxicity seems to play a major role in the infection with other rickettsiae such as $R$. australis.

\section{$\mathrm{CD4}^{+} \mathrm{T}$ cells}

The enhanced susceptibility of $\mathrm{C} 3 \mathrm{H} / \mathrm{HeN}$ mice to the infection with $R$. conorii compared to C57BL/6 mice has been connected to the reduced ability of DCs to induce IFN $\gamma$ producing $\mathrm{CD}^{+}{ }^{+} \mathrm{T}$ cells. Bone marrow-derived DCs from $\mathrm{C} 3 \mathrm{H} / \mathrm{HeN}$ mice that were infected with $R$. conorii showed lower expression of MHCII, reduced release of IL-12p40 and a lower capacity to induce IFN $\gamma$ release by $\mathrm{CD} 4^{+} \mathrm{T}$ cells than DCs from C57BL/6 mice in vitro [100]. In vivo C3H/ $\mathrm{HeN}$ mice develop higher frequencies of $\mathrm{FoxP}^{+}$regulatory $\mathrm{T}$ cells than C57BL/6 mice upon $R$. conorii infection which is discussed as a consequence of suppressed $\mathrm{CD} 4^{+} \mathrm{T}$ cell response in these mice [100]. Adoptive transfer of immune $\mathrm{CD}^{+}{ }^{+} \mathrm{T}$ cells, however, protects $\mathrm{C} 3 \mathrm{H} / \mathrm{HeN}$ mice against lethal infection with $R$. conorii [99].

Meanwhile, there is increasing evidence that $\mathrm{CD} 4^{+} \mathrm{T}$ cells are sufficient for protection, at least against some rickettsiae. This is clearly true for the infection of mice with $R$. typhi. C57BL/6 $\mathrm{MHCI}^{-1-}$ that lack CD8 ${ }^{+} \mathrm{T}$ cells do not develop disease and survive the infection with $R$. typhi [47] which is in contrast to the infection with $R$. australis where $\mathrm{CD} 8^{+} \mathrm{T}$ cells obviously play a dominant role in defense [46]. Even more important, immune $\mathrm{CD}^{+}{ }^{+} \mathrm{T}$ cells protect $\mathrm{C} 57 \mathrm{BL} / 6$ $\mathrm{RAG1}^{-1-}$ mice against lethal challenge with $R$. typhi [47]. Here, $\mathrm{CD} 4^{+} \mathrm{T}$ cells still protect a large percentage of animals with already established infection. Although $\mathrm{CD} 8^{+} \mathrm{T}$ cells are obviously more efficient and quicker in bacterial elimination in this system, $\mathrm{CD}^{+}{ }^{+} \mathrm{T}$ cells manage to control the bacteria. $R$. typhi was not detectable anymore even in those mice that succumbed to the infection despite $\mathrm{CD}^{+}{ }^{+} \mathrm{T}$ cell transfer [47]. Similar to $\mathrm{CD} 8^{+} \mathrm{T}$ cells, $\mathrm{CD} 4^{+} \mathrm{T}$ cells enter the CNS of the animals where they induce the expression of iNOS in infiltrating $\mathrm{M} \Phi$ that harbor $R$. typhi in these mice [33] as well as in microglia which is not observed in $\mathrm{CD}^{+} \mathrm{T}$ cell recipient mice [47]. Thus, $\mathrm{CD}^{+} \mathrm{T}$ cells enhance the bactericidal activity of these cells in vivo. Activation of microglia and $\mathrm{M} \Phi$ by $\mathrm{CD} 4^{+} \mathrm{T}$ cells, however, can have pathological effects. R. typhi-infected C57BL/6 RAG1 ${ }^{-/-}$that succumbed to the infection despite $\mathrm{CD} 4^{+} \mathrm{T}$ cell transfer still showed enhanced activation of $\mathrm{M} \Phi$ and microglia in the CNS despite bacterial elimination [47]. In these cases immunopathology seems to be the reason of death.

$\mathrm{CD}^{+} \mathrm{T}$ cells express IFN $\gamma$ in the infection of C57BL/6 as well as of BALB/c mice with $R$. typhi $[45,47]$. Generally, the $\mathrm{CD} 4^{+} \mathrm{T}$ cell response in these mice appears with similar kinetics as the $\mathrm{CD}^{+} \mathrm{T}$ cell response. Activated $\mathrm{CD} 4^{+} \mathrm{T}$ cells peak on day 7 post infection but do not return to basal levels again, and sporadic reactivation of $\mathrm{CD} 4^{+} \mathrm{T}$ cells is observed in $R$. typhi-infected BALB/c mice [45, 47]. Upon antigen-specific restimulation in vitro $\mathrm{CD} 4^{+} \mathrm{T}$ cells from R. typhi-infected $\mathrm{BALB} / \mathrm{c}$ mice release very high amounts of IFN $\gamma$ in addition to lower amounts of TNF $\alpha$. Both of these cytokines have been shown to play an important role in defense against $R$. conorii. The neutralization of either IFN $\gamma$ or TNF $\alpha$ leads to enhanced pathology in $R$. conorii-infected $\mathrm{C} 3 \mathrm{H} / \mathrm{HeN}$ mice, and IFN $\gamma$-deficient $\mathrm{C} 57 \mathrm{BL} / 6$ mice succumb to the infection with a normally sublethal dose of $R$. conorii [101]. Both cytokines likely also play a role in protection against $R$. typhi by $\mathrm{CD} 4^{+} \mathrm{T}$ cells. Immune $\mathrm{CD} 4^{+} \mathrm{T}$ cells from either C57BL/6 or BALB/c mice induce the release of NO from R. typhi-infected $\mathrm{M} \Phi$ and inhibit bacterial growth in vitro. This effect is partially inhibited by the neutralization of IFN $\gamma$ or TNF $\alpha[45,47]$. CD4 ${ }^{+} \mathrm{T}$ cells adoptively transferred into $R$. typhi-infected CB17 SCID mice protect approximately $90 \%$ of the animals from death and provide long-term control of the bacteria [45]. CD4 ${ }^{+} \mathrm{IFN} \gamma^{-1-} \mathrm{T}$ cells, however, still reduce the growth of $R$. typhi in infected $\mathrm{M} \Phi$ in vitro. Moreover, $\mathrm{CD}^{+} \mathrm{IFN}^{-1-} \mathrm{T}$ cells are able to eliminate the bacteria and confer protection against $R$. typhi in vivo. 30-90\% of $R$ typhi-infected CB17 SCID mice that receive these cells survive the infection although showing prolonged disease compared to mice that are substituted with wild-type $\mathrm{CD}^{+} \mathrm{T}$ cells [45]. The authors further show that $\mathrm{CD}^{+} \mathrm{T}$ cells develop into $\mathrm{T}_{\mathrm{H}} 17$ cells in the infection with $R$. typhi in the absence of IFN $\gamma$. Instead of IFN $\gamma, \mathrm{CD} 4^{+} \mathrm{T}$ cells from $R$. typhi-infected BALB/c IFN $\gamma^{-/-}$mice release large amounts of IL-17A and IL-22 and low amounts of IL-17F. These cytokines are not produced at all by immune $\mathrm{CD}^{+}{ }^{+} \mathrm{T}$ cells from $R$. typhi-infected wild-type BALB/c mice [45], whereas TNF $\alpha$ is released at comparable amounts by both wild-type $\mathrm{CD} 4^{+}$and $\mathrm{CD} 4^{+} \mathrm{IFN} \gamma^{-1-} \mathrm{T}$ cells [45]. Other cytokines such as IL-21 that could be involved in bacterial defense are not detectable. Although $\mathrm{T}_{\mathrm{H}} 17$ cells are thought to be mainly involved in defense against extracellular pathogens, cytokines that are produced by these cells can directly 
contribute to protection against intracellular pathogens. IL$17 \mathrm{~A} / \mathrm{F}$ induce the expression of inflammatory cyokines such as TNF $\alpha$, IL- $1 \beta$ and IL-6 in tissue cells and M $\Phi$ [102-106] and of antimicrobial peptides in tissue cells in concert with IL-22 [107, 108]. Moreover, IL-17A has been shown to promote the expression of iNOS and the release of NO by MФ infected with Mycobacterium bovis bacillus CalmetteGuerin (BCG) [109] and to inhibit the growth of intracellular parasites such as Chlamydia muridarum in lung epithelial cells and $M \Phi$ in vitro in an iNOS-dependent manner [110] and of Trypanosoma cruzi in infected MФ in vitro which is mediated via the activation of the NAPDH oxidase [111]. This enzyme produces superoxide and other ROS that mediate killing of intracellular pathogens in $М \Phi$ and neutrophils similar to NO [112]. Also IL-22 can directly induce microbicidal activity. The growth of Eimeria falciformis in infected epithelial cells is inhibited by the treatment with either IFN $\gamma$, IL-17A or IL-22 [113]. Furthermore, IL-17A/F induce the release of granulopoetic factors (G-CSF, GM-CSF, SCF) and several chemokines (CXCL-1, CXCL-2, CXCL-5, CXCL-8) that lead to the recruitment of neutrophils that can further contribute to pathogen elimination [114]. Similar mechanisms may be true for defense against $R$. typhi by $\mathrm{T}_{\mathrm{H}} 17$ cells.

Apart from that, IL-17A/F and TNF $\alpha$ can also have pathological effects, which is clearly true in the infection with $R$. typhi. The neutralization of either TNF $\alpha$ or IL-17A leads to much milder disease and enhanced survival of $R$. typhiinfected CB17 SCID mice that received CD $4^{+} \mathrm{IFN} \gamma^{-1-} \mathrm{T}_{\mathrm{H}} 17$ cells [45]. These observations suggest that TNF $\alpha$ and IL-17A exert synergistic pathologcial effects in $R$. typhi-infected mice as described for other inflammatory conditions $[115,116]$, while combined release of IL-22 and TNF $\alpha$ or IL-22 and $\mathrm{IL}-17 \mathrm{~A}$ is beneficial and sufficient for protection. Whether $\mathrm{T}_{\mathrm{H}} 17$ cells play a role in protection and/or pathology in human infection with $R$. typhi is unknown, but one may imagine that these cells may be generated in patients with defective induction of $T_{H} 1$ cells, leading to more severe disease. Interestingly, patients with scrub typhus show higher levels of IL-17 than healthy individuals [117]. Moreover, IL-17 levels in patients with headache are higher than in patients without headache, and it is discussed whether IL-17 may be involved in pathophysiology in the infection with $O$. tsutsugamushi, although a direct correlation has not been demonstrated yet [117].

The current hypothesis on the mode of action of $\mathrm{CD}^{+}$ $\mathrm{T}$ cells is that $\mathrm{CD}^{+}{ }^{+} \mathrm{T}$ cell-derived cytokines, either IFN $\gamma$ and TNF $\alpha$ in case of $\mathrm{T}_{\mathrm{H}} 1$ cells or IL-17A and TNF $\alpha$ in case of $\mathrm{T}_{\mathrm{H}} 17$ cells, directly act on $\mathrm{M} \Phi$ and also neutrophils to activate the bactericidal activity of these cells. IL-22 may contribute to protection by the induction of antimicrobial peptides and other factors in infected non-immune cells such as fibroblasts and endothelial cells. Figure 2 provides an overview on the hypothetic action of $\mathrm{CD} 8^{+} \mathrm{T}$ cells, $\mathrm{T}_{\mathrm{H}} 1$ and $\mathrm{T}_{\mathrm{H}} 17$ cells in defense against rickettsiae. The exact mechanisms how $T_{H} 17$ cells mediate protection and/or contribute to pathology in rickettsial infections, however, remain to be elucidated.

\section{$T$ cell-mediated cross-protection and $T$ cell antigens}

Cross-protective immune response between different rickettsial species has been described for animals as well as for humans. Guinea pigs experimentally infected with $R$. typhi are immune to $R$. prowazekii infection and vice versa, and similar solid cross-immunity exists for humans [118]. Spleen cells from $R$. conorii-infected $\mathrm{C} 3 \mathrm{H} / \mathrm{HeJ}$ mice react to antigen preparations from $R$. rickettsii, $R$. sibirica and $R$. australis, but only poorly to $R$. akari, while spleen cells from R. akari-immunized C3H/ HeJ mice react to $R$. conorii and other SFG rickettsiae [119]. Moreover, $\mathrm{C} 3 \mathrm{H} / \mathrm{HeN}$ mice that are infected with a sublethal dose of either $R$. conorii or $R$. australis are protected against a normally lethal challenge with the heterologous pathogen [120]. The same is also true for $R$. conorii- and $R$. typhiinfected $\mathrm{C} 3 \mathrm{H} / \mathrm{HeN}$ mice [121], demonstrating cross-protection even between SFG and TG rickettsiae and SFG and transitional rickettsiae. Therefore, the identification of immunodominant $\mathrm{T}$ cell antigens that are present in a broader range of rickettsiae may lead to the identification of vaccine candidates that can confer protection even against various rickettsiae.

Very recently, five protective $R$. prowazekii $\mathrm{CD} 8^{+} \mathrm{T}$ cell antigens (RP884, RP778, RP739, RP598 and RP403) have been discovered $[122,123]$. $\mathrm{C} 3 \mathrm{H} / \mathrm{HeN}$ mice that were immunized with antigen-presenting cells (APCs) expressing these antigens developed $\mathrm{CD} 8^{+} \mathrm{T}$ cells that expressed IFN $\gamma$ and Granzym B. Moreover, the animals were protected against a lethal challenge with $R$. typhi $[122,123]$. APCs expressing a mix of these antigens were further used for the immunization of $\mathrm{C} 3 \mathrm{H} / \mathrm{HeN}$ mice followed by the infection with $R$. conorii and conferred at least partial protection [123]. $\mathrm{CD}^{+} \mathrm{T}$ cell epitopes have also been identified in the OmpB protein of $R$. conorii. Three synthetic peptides of OmpB (SKGVNVDTV $\left(\mathrm{OmpB}_{708-716}\right)$, ANSTLQIGG $\left(\mathrm{OmpB}_{789-797}\right)$ and IVEFVNTGP $\left.\left(\mathrm{OmpB}_{812-820}\right)\right)$ induced proliferation, cytotoxic activity, and IFN $\gamma$ expression by $\mathrm{CD}^{+} \mathrm{T}$ cells from $R$. conorii-infected $\mathrm{C} 3 \mathrm{H} / \mathrm{HeN}$ mice [124]. These proteins and peptides can, therefore, be considered as vaccine candidates. The induction of $\mathrm{CD} 8^{+} \mathrm{T}$ cells, however, is difficult because antigens must be provided to the MHC class I presentation pathway within target cells, which requires cytosolic expression of the respective protein.

Recent findings suggest that $\mathrm{CD} 4^{+} \mathrm{T}$ cells can be as protective as $\mathrm{CD}^{+} \mathrm{T}$ cells. Therefore, the induction of $\mathrm{CD} 4^{+} \mathrm{T}$ cells by vaccination may be sufficient for protection against rickettsial infections. $\mathrm{CD} 4^{+} \mathrm{T}$ cells are much easier to induce than $\mathrm{CD}^{+} \mathrm{T}$ cells by the application of recombinant protein antigen, leading to MHC class II peptide presentation. So far, only the 22-kDa scrub typhus antigen (sta22) was identified as an antigen against which antibodies as well as 


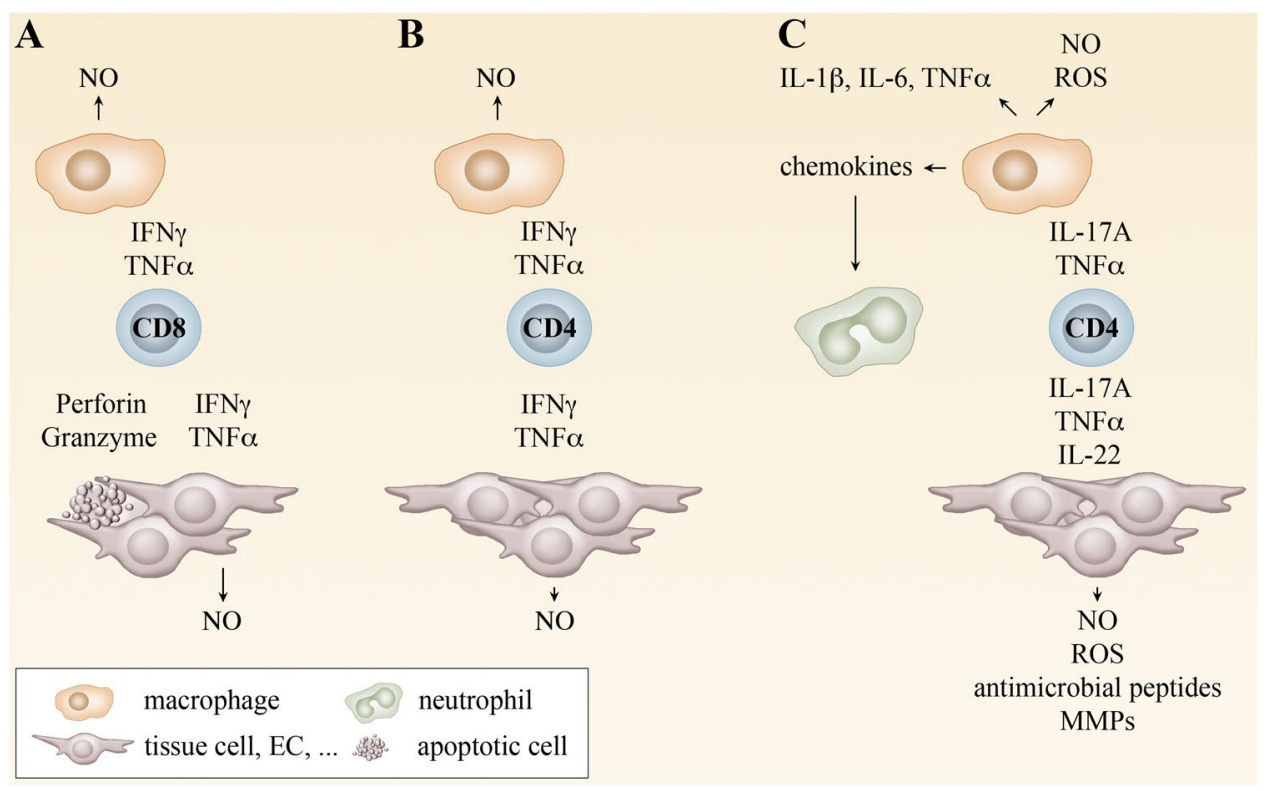

Fig. 2 Mechanisms of T cell-mediated protection. CD8 ${ }^{+} \mathrm{T}$ cells differentiate in the infection with rickettsiae to cytotoxic $\mathrm{T}$ cells that induce apoptosis in infected cells via the release of perforin and granzymes. In addition, $\mathrm{CD}^{+} \mathrm{T}$ cells produce IFN $\gamma$ and $\mathrm{TNF} \alpha$. These cytokines induce the production of NO by M $\Phi$ and other cells and, thus, enable bacterial killing. The release of cytokines by $\mathrm{CD} 8^{+} \mathrm{T}$ cells is sufficient for protection at least in the infection with some rickettsial species such as $R$. typhi where the cytotoxic activity is not essential for bacterial defense (a). $\mathrm{CD}^{+} \mathrm{T}$ cells usually differentiate into $\mathrm{T}_{\mathrm{H}} 1$ cells that produce IFN $\gamma$ and $\mathrm{TNF} \alpha$ in the infection with rickettsiae. $\mathrm{T}_{\mathrm{H}} 1$ cells are protective by the induction of $\mathrm{NO}$ and bacterial killing by $\mathrm{M} \Phi$ and other cells (b). In the absence of IFN $\gamma, \mathrm{CD}^{+} \mathrm{T}$ cells develop into $T_{H} 17$ cells in the infection with rickettsiae. These

$\mathrm{CD} 4^{+} \mathrm{T}$ cells are generated in $O$. tsutsugamushi-infected mice [125]. $\mathrm{CD}^{+} \mathrm{T}$ cell antigens from other rickettsial species are still unknown.

\section{Concluding remarks}

Murine models of rickettsial infections have significantly advanced the understanding of immune response against these bacteria. Importantly, not only $\mathrm{CD} 8^{+} \mathrm{T}$ cells but also $\mathrm{CD}^{+} \mathrm{T}$ cells can mediate protection. With regard to vaccination, current knowledge suggests that the induction of specific $\mathrm{CD}^{+} \mathrm{T}$ cells is sufficient for protection, at least against some rickettsial species. Therefore, $\mathrm{CD} 4^{+} \mathrm{T}$ cell antigens should be identified for the development of a vaccine that induces IFN $\gamma$-producing $\mathrm{T}_{\mathrm{H}} 1$ cells. These cells will likely exert less side effects than $\mathrm{T}_{\mathrm{H}} 17$ cells. Such vaccine may even confer cross-protectivity between different rickettsial species.

Open Access This article is distributed under the terms of the Creative Commons Attribution 4.0 International License (http:// cells release IL-17A, IL-22 and TNF $\alpha$. IL-17A and TNF $\alpha$ synergistically induce the production of NO und ROS by M $\Phi$ and other cells. In addition, these cytokines induce the release of proinflammatory cytokines. IL-17A further induces the production of chemokines, leading to the recruitment of neutrophils that contribute to local inflammation. IL-22 does not act on immune cells but various tissue cells. IL-22 induces the release of antimicrobial peptides and other factors and can contribute in this way to bacterial elimination. At least in the infection with $R$. typhi $\mathrm{T}_{\mathrm{H}} 17$ cells can be protective. However, the combined release of TNF $\alpha$ and IL-17A is non-beneficial and exerts pathological effects. Inhibition of either TNF $\alpha$ or IL-17A in this situation renders $T_{H} 17$ cells as protective as $T_{H} 1$ cells (c)

creativecommons.org/licenses/by/4.0/), which permits unrestricted use, distribution, and reproduction in any medium, provided you give appropriate credit to the original author(s) and the source, provide a link to the Creative Commons license, and indicate if changes were made.

\section{References}

1. Mediannikov O, Nguyen TT, Bell-Sakyi L, Padmanabhan R, Fournier PE, Raoult D (2014) High quality draft genome sequence and description of Occidentia massiliensis gen. nov., sp. nov., a new member of the family Rickettsiaceae. Stand Genomic Sci 9:9. doi:10.1186/1944-3277-9-9

2. Sekeyova Z, Roux V, Raoult D (2001) Phylogeny of Rickettsia spp. inferred by comparing sequences of 'gene D', which encodes an intracytoplasmic protein. Int J Syst Evol Microbiol 51(Pt 4):1353-1360

3. Mansueto P, Vitale G, Cascio A, Seidita A, Pepe I, Carroccio A, di Rosa S, Rini GB, Cillari E, Walker DH (2012) New insight into immunity and immunopathology of Rickettsial diseases. Clin Dev Immunol 2012:967852. doi:10.1155/2012/967852

4. Murray GG, Weinert LA, Rhule EL, Welch JJ (2016) The phylogeny of rickettsia using different evolutionary signatures: how tree-like is bacterial evolution? Syst Biol 65(2):265-279. doi:10.1093/sysbio/syv084 
5. Beier-Sexton M, Driscoll T, Azad AF, Gillespie JJ (2015) The family Rickettsiaceae. Practical handbook of microbiology, 3rd edn, pp 547-563. doi:10.1201/9781420009330.ch28

6. Sahni SK, Rydkina E (2009) Host-cell interactions with pathogenic Rickettsia species. Future Microbiol 4(3):323-339. doi: $10.2217 / \mathrm{fmb} .09 .6$

7. Winkler HH, Miller ET (1982) Phospholipase A and the interaction of Rickettsia prowazekii and mouse fibroblasts (L-929 cells). Infect Immun 38(1):109-113

8. Silverman DJ, Santucci LA, Meyers N, Sekeyova Z (1992) Penetration of host cells by Rickettsia rickettsii appears to be mediated by a phospholipase of rickettsial origin. Infect Immun 60(7):2733-2740

9. Walker DH, Feng HM, Popov VL (2001) Rickettsial phospholipase A2 as a pathogenic mechanism in a model of cell injury by typhus and spotted fever group rickettsiae. Am J Trop Med Hyg 65(6):936-942

10. Renesto P, Dehoux P, Gouin E, Touqui L, Cossart P, Raoult D (2003) Identification and characterization of a phospholipase D-superfamily gene in rickettsiae. J Infect Dis 188(9):12761283. doi:10.1086/379080

11. Rahman MS, Gillespie JJ, Kaur SJ, Sears KT, Ceraul SM, Beier-Sexton M, Azad AF (2013) Rickettsia typhi possesses phospholipase A2 enzymes that are involved in infection of host cells. PLoS Pathog 9(6):e1003399. doi:10.1371/journal. ppat.1003399

12. Silverman DJ, Bond SB (1984) Infection of human vascular endothelial cells by Rickettsia rickettsii. J Infect Dis 149(2):201-206

13. Hackstadt $T$ (1996) The biology of rickettsiae. Infect Agents Dis 5(3):127-143

14. Heinzen RA (2003) Rickettsial actin-based motility: behavior and involvement of cytoskeletal regulators. Ann N Y Acad Sci 990:535-547

15. Gouin E, Welch MD, Cossart P (2005) Actin-based motility of intracellular pathogens. Curr Opin Microbiol 8(1):35-45. doi:10.1016/j.mib.2004.12.013

16. Kim MJ, Kim MK, Kang JS (2013) Involvement of lipid rafts in the budding-like exit of Orientia tsutsugamushi. Microb Pathog 63:37-43. doi:10.1016/j.micpath.2013.06.002

17. Radulovic S, Price PW, Beier MS, Gaywee J, Macaluso JA, Azad A (2002) Rickettsia-macrophage interactions: host cell responses to Rickettsia akari and Rickettsia typhi. Infect Immun 70(5):2576-2582

18. Walker DH, Popov VL, Wen J, Feng HM (1994) Rickettsia conorii infection of $\mathrm{C} 3 \mathrm{H} / \mathrm{HeN}$ mice. A model of endothelialtarget rickettsiosis. Lab Invest 70(3):358-368

19. Pongponratn E, Maneerat Y, Chaisri U, Wilairatana P, Punpoowong B, Viriyavejakul P, Riganti M (1998) Electron-microscopic examination of Rickettsia tsutsugamushi-infected human liver. Trop Med Int Health 3(3):242-248

20. Walker DH, Harrison A, Henderson F, Murphy FA (1977) Identification of Rickettsia rickettsii in a guinea pig model by immunofluorescent and electron microscopic techniques. Am J Pathol 86(2):343-358

21. Joshi SG, Kovacs AD (2007) Rickettsia rickettsii infection causes apoptotic death of cultured cerebellar granule neurons. J Med Microbiol 56(Pt 1):138-141. doi:10.1099/jmm.0.46826-0

22. McDade JE, Stakebake JR, Gerone PJ (1969) Plaque assay system for several species of Rickettsia. J Bacteriol 99(3):910-912

23. Wike DA, Tallent G, Peacock MG, Ormsbee RA (1972) Studies of the rickettsial plaque assay technique. Infect Immun 5(5):715-722

24. Hanson B (1987) Improved plaque assay for Rickettsia tsutsugamushi. Am J Trop Med Hyg 36(3):631-638
25. Policastro PF, Peacock MG, Hackstadt $T$ (1996) Improved plaque assays for Rickettsia prowazekii in Vero 76 cells. J Clin Microbiol 34(8):1944-1948

26. Raoult D, Woodward T, Dumler JS (2004) The history of epidemic typhus. Infect Dis Clin North Am 18(1):127-140. doi:10.1016/S0891-5520(03)00093-X

27. Kuloglu F (2013) Rickettsial infections. Dis Mol Med 1(2):39-45

28. Dill T, Dobler G, Saathoff E, Clowes P, Kroidl I, Ntinginya E, Machibya H, Maboko L, Loscher T, Hoelscher M, Heinrich N (2013) High seroprevalence for typhus group rickettsiae, southwestern Tanzania. Emerg Infect Dis 19(2):317-320. doi:10.3201/ eid1902.120601

29. Bechah Y, Paddock CD, Capo C, Mege JL, Raoult D (2010) Adipose tissue serves as a reservoir for recrudescent Rickettsia prowazekii infection in a mouse model. PLoS One 5(1):e8547. doi:10.1371/journal.pone.0008547

30. Chung MH, Lee JS, Baek JH, Kim M, Kang JS (2012) Persistence of Orientia tsutsugamushi in humans. J Korean Med Sci 27(3):231-235. doi:10.3346/jkms.2012.27.3.231

31. Parker RT, Menon PG, Merideth AM, Snyder MJ, Woodward TE (1954) Persistence of Rickettsia rickettsii in a patient recovered from Rocky Mountain spotted fever. J Immunol 73(6):383-386

32. Hove MG, Walker DH (1995) Persistence of rickettsiae in the partially viable gangrenous margins of amputated extremities 5 to 7 weeks after onset of Rocky Mountain spotted fever. Arch Pathol Lab Med 119(5):429-431

33. Osterloh A, Papp S, Moderzynski K, Kuehl S, Richardt U, Fleischer B (2016) Persisting Rickettsia typhi causes fatal central nervous system inflammation. Infect Immun 84(5):1615-1632. doi:10.1128/IAI.00034-16

34. Stein A, Purgus R, Olmer M, Raoult D (1999) Brill-Zinsser disease in France. Lancet 353(9168):1936. doi:10.1016/ S0140-6736(99)01995-9

35. Turcinov D, Kuzman I, Herendic B (2000) Failure of azithromycin in treatment of Brill-Zinsser disease. Antimicrob Agents Chemother 44(6): 1737-1738

36. Lutwick LI (2001) Brill-Zinsser disease. Lancet 357(9263):1198-1200

37. Faucher JF, Socolovschi C, Aubry C, Chirouze C, HustacheMathieu L, Raoult D, Hoen B (2012) Brill-Zinsser disease in Moroccan man, France, 2011. Emerg Infect Dis 18(1):171-172. doi:10.3201/eid1801.111057

38. Feng HM, Wen J, Walker DH (1993) Rickettsia australis infection: a murine model of a highly invasive vasculopathic rickettsiosis. Am J Pathol 142(5):1471-1482

39. Anderson GW Jr, Osterman JV (1980) Host defenses in experimental rickettsialpox: genetics of natural resistance to infection. Infect Immun 28(1):132-136

40. Papp S, Moderzynski K, Rauch J, Heine L, Kuehl S, Richardt U, Mueller H, Fleischer B, Osterloh A (2016) Liver necrosis and lethal systemic inflammation in a murine model of Rickettsia typhi Infection: role of neutrophils, macrophages and NK cells. PLoS Negl Trop Dis 10(8):e0004935. doi:10.1371/ journal.pntd.0004935

41. Keller CA, Hauptmann M, Kolbaum J, Gharaibeh M, Neumann M, Glatzel M, Fleischer B (2014) Dissemination of Orientia tsutsugamushi and inflammatory responses in a murine model of scrub typhus. PLoS Negl Trop Dis 8(8):e3064. doi:10.1371/ journal.pntd.0003064

42. Groves MG, Kelly DJ (1989) Characterization of factors determining Rickettsia tsutsugamushi pathogenicity for mice. Infect Immun 57(5):1476-1482

43. Groves MG, Osterman JV (1978) Host defenses in experimental scrub typhus: genetics of natural resistance to infection. Infect Immun 19(2):583-588 
44. Fang R, Ismail N, Walker DH (2012) Contribution of NK cells to the innate phase of host protection against an intracellular bacterium targeting systemic endothelium. Am J Pathol 181(1):185-195. doi:10.1016/j.ajpath.2012.03.020

45. Moderzynski K, Heine L, Rauch J, Papp S, Kuehl S, Richardt U, Fleischer B, Osterloh A (2017) Cytotoxic effector functions of $\mathrm{T}$ cells are not required for protective immunity against fatal Rickettsia typhi infection in a murine model of infection: role of TH1 and TH17 cytokines in protection and pathology. PLoS Negl Trop Dis 11(2):e0005404. doi:10.1371/journal. pntd.0005404

46. Walker DH, Olano JP, Feng HM (2001) Critical role of cytotoxic $\mathrm{T}$ lymphocytes in immune clearance of rickettsial infection. Infect Immun 69(3):1841-1846. doi:10.1128/IAI.69.3.1841-1846.2001

47. Moderzynski K, Papp S, Rauch J, Heine L, Kuehl S, Richardt U, Fleischer B, Osterloh A (2016) CD4+ T cells are as protective as CD8+ T Cells against Rickettsia typhi Infection by activating macrophage bactericidal activity. PLoS Negl Trop Dis 10(11):e0005089. doi:10.1371/journal.pntd.0005089

48. Smalley C, Bechelli J, Rockx-Brouwer D, Saito T, Azar SR, Ismail N, Walker DH, Fang R (2016) Rickettsia australis activates inflammasome in human and murine macrophages. PLoS One 11(6):e0157231. doi:10.1371/journal.pone.0157231

49. Walker DH, Popov VL, Feng HM (2000) Establishment of a novel endothelial target mouse model of a typhus group rickettsiosis: evidence for critical roles for gamma interferon and CD8 T lymphocytes. Lab Invest 80(9):1361-1372

50. Grasperge BJ, Reif KE, Morgan TD, Sunyakumthorn P, Bynog J, Paddock CD, Macaluso KR (2012) Susceptibility of inbred mice to Rickettsia parkeri. Infect Immun 80(5):1846-1852. doi:10.1128/IAI.00109-12

51. Eisemann CS, Nypaver MJ, Osterman JV (1984) Susceptibility of inbred mice to rickettsiae of the spotted fever group. Infect Immun 43(1):143-148

52. Jordan JM, Woods ME, Olano J, Walker DH (2008) The absence of Toll-like receptor 4 signaling in $\mathrm{C} 3 \mathrm{H} / \mathrm{HeJ}$ mice predisposes them to overwhelming rickettsial infection and decreased protective Th1 responses. Infect Immun 76(8):3717-3724. doi:10.1128/ IAI.00311-08

53. Feng HM, Whitworth T, Olano JP, Popov VL, Walker DH (2004) Fc-dependent polyclonal antibodies and antibodies to outer membrane proteins A and B, but not to lipopolysaccharide, protect SCID mice against fatal Rickettsia conorii infection. Infect Immun 72(4):2222-2228

54. Clifton DR, Rydkina E, Huyck H, Pryhuber G, Freeman RS, Silverman DJ, Sahni SK (2005) Expression and secretion of chemotactic cytokines IL- 8 and MCP-1 by human endothelial cells after Rickettsia rickettsii infection: regulation by nuclear transcription factor NF-kappaB. Int J Med Microbiol 295(4):267-278

55. Kaplanski G, Teysseire N, Farnarier C, Kaplanski S, Lissitzky JC, Durand JM, Soubeyrand J, Dinarello CA, Bongrand P (1995) IL-6 and IL-8 production from cultured human endothelial cells stimulated by infection with Rickettsia conorii via a cell-associated IL-1 alpha-dependent pathway. J Clin Invest 96(6):28392844. doi:10.1172/JCI118354

56. Valbuena G, Bradford W, Walker DH (2003) Expression analysis of the T-cell-targeting chemokines CXCL9 and CXCL10 in mice and humans with endothelial infections caused by rickettsiae of the spotted fever group. Am J Pathol 163(4):1357-1369. doi:10.1016/S0002-9440(10)63494-3

57. Bechah Y, Capo C, Raoult D, Mege JL (2008) Infection of endothelial cells with virulent Rickettsia prowazekii increases the transmigration of leukocytes. J Infect Dis 197(1):142-147. doi:10.1086/523649

58. Baggiolini M, Clark-Lewis I (1992) Interleukin-8, a chemotactic and inflammatory cytokine. FEBS Lett 307(1):97-101
59. Harada A, Sekido N, Akahoshi T, Wada T, Mukaida N, Matsushima K (1994) Essential involvement of interleukin-8 (IL-8) in acute inflammation. J Leukoc Biol 56(5):559-564

60. Russo RC, Garcia CC, Teixeira MM, Amaral FA (2014) The CXCL8/IL-8 chemokine family and its receptors in inflammatory diseases. Expert Rev Clin Immunol 10(5):593-619. doi:10.1586 /1744666X.2014.894886

61. Li A, Dubey S, Varney ML, Dave BJ, Singh RK (2003) IL-8 directly enhanced endothelial cell survival, proliferation, and matrix metalloproteinases production and regulated angiogenesis. J Immunol 170(6):3369-3376

62. Deshmane SL, Kremlev S, Amini S, Sawaya BE (2009) Monocyte chemoattractant protein-1 (MCP-1): an overview. J Interferon Cytokine Res 29(6):313-326. doi:10.1089/jir.2008.0027

63. Shi C, Pamer EG (2011) Monocyte recruitment during infection and inflammation. Nat Rev Immunol 11(11):762-774. doi:10.1038/nri3070

64. Groom JR, Luster AD (2011) CXCR3 ligands: redundant, collaborative and antagonistic functions. Immunol Cell Biol 89(2):207-215. doi:10.1038/icb.2010.158

65. Sporn LA, Lawrence SO, Silverman DJ, Marder VJ (1993) E-selectin-dependent neutrophil adhesion to Rickettsia rickettsiiinfected endothelial cells. Blood 81(9):2406-2412

66. Valbuena G, Walker DH (2004) Effect of blocking the CXCL9/10-CXCR3 chemokine system in the outcome of endothelial-target rickettsial infections. Am J Trop Med Hyg 71(4):393-399

67. Elices MJ, Osborn L, Takada Y, Crouse C, Luhowskyj S, Hemler ME, Lobb RR (1990) VCAM-1 on activated endothelium interacts with the leukocyte integrin VLA-4 at a site distinct from the VLA-4/fibronectin binding site. Cell 60(4):577-584

68. Sporn LA, Marder VJ (1996) Interleukin-1 alpha production during Rickettsia rickettsii infection of cultured endothelial cells: potential role in autocrine cell stimulation. Infect Immun 64(5):1609-1613

69. Dinarello CA (2009) Immunological and inflammatory functions of the interleukin-1 family. Annu Rev Immunol 27:519-550. doi:10.1146/annurev.immunol.021908.132612

70. Scheller J, Chalaris A, Schmidt-Arras D, Rose-John S (2011) The pro- and anti-inflammatory properties of the cytokine interleukin-6. Biochem Biophys Acta 1813 5:878-888. doi:10.1016/j. bbamcr.2011.01.034

71. Chan ED, Riches DW (1998) Potential role of the JNK/SAPK signal transduction pathway in the induction of iNOS by TNF-alpha. Biochem Biophys Res Commun 253(3):790-796. doi:10.1006/bbrc.1998.9857

72. Rydkina E, Sahni A, Baggs RB, Silverman DJ, Sahni SK (2006) Infection of human endothelial cells with spotted Fever group rickettsiae stimulates cyclooxygenase 2 expression and release of vasoactive prostaglandins. Infect Immun 74(9):5067-5074. doi:10.1128/IAI.00182-06

73. Walker TS, Brown JS, Hoover CS, Morgan DA (1990) Endothelial prostaglandin secretion: effects of typhus rickettsiae. J Infect Dis 162(5):1136-1144

74. Zimmerman GA, McIntyre TM, Prescott SM, Stafforini DM (2002) The platelet-activating factor signaling system and its regulators in syndromes of inflammation and thrombosis. Crit Care Med 30(5 Suppl):S294-S301

75. Sporn LA, Haidaris PJ, Shi RJ, Nemerson Y, Silverman DJ, Marder VJ (1994) Rickettsia rickettsii infection of cultured human endothelial cells induces tissue factor expression. Blood 83(6):1527-1534

76. Butenas S (2012) Tissue factor structure and function. Scientifica 2012:964862. doi:10.6064/2012/964862

77. Sporn LA, Sahni SK, Lerner NB, Marder VJ, Silverman DJ, Turpin LC, Schwab AL (1997) Rickettsia rickettsii infection of 
cultured human endothelial cells induces NF-kappaB activation. Infect Immun 65(7):2786-2791

78. Shi RJ, Simpson-Haidaris PJ, Lerner NB, Marder VJ, Silverman DJ, Sporn LA (1998) Transcriptional regulation of endothelial cell tissue factor expression during Rickettsia rickettsii infection: involvement of the transcription factor NF-kappaB. Infect Immun 66(3):1070-1075

79. Clifton DR, Goss RA, Sahni SK, van Antwerp D, Baggs RB, Marder VJ, Silverman DJ, Sporn LA (1998) NF-kappa B-dependent inhibition of apoptosis is essential for host cellsurvival during Rickettsia rickettsii infection. Proc Natl Acad Sci USA 95(8):4646-4651

80. Walker DH, Hudnall SD, Szaniawski WK, Feng HM (1999) Monoclonal antibody-based immunohistochemical diagnosis of rickettsialpox: the macrophage is the principal target. Mod Pathol 12(5):529-533

81. Nelyubov MV (2002) Astrakhan scrub typhus: time course of infectious process according to electron microscopy findings. Bull Exp Biol Med 134(4):374-375

82. Bechelli J, Smalley C, Zhao X, Judy B, Valdes P, Walker DH, Fang R (2016) MyD88 mediates instructive signaling in dendritic cells and protective inflammatory response during rickettsial infection. Infect Immun 84(4):883-893. doi:10.1128/ IAI.01361-15

83. Takeda K, Akira S (2015) Toll-like receptors. Curr Protoc Immunol 109:14.12.1-14.12.10. doi:10.1002/0471142735.im1412s109

84. Quevedo-Diaz MA, Song C, Xiong Y, Chen H, Wahl LM, Radulovic S, Medvedev AE (2010) Involvement of TLR2 and TLR4 in cell responses to Rickettsia akari. J Leukoc Biol 88(4):675-685. doi:10.1189/jlb.1009674

85. Gharaibeh M, Hagedorn M, Lilla S, Hauptmann M, Heine H, Fleischer B, Keller C (2016) Toll-like receptor 2 recognizes Orientia tsutsugamushi and increases susceptibility to murine experimental scrub typhus. Infect Immun 84(12):3379-3387. doi:10.1128/IAI.00185-16

86. Drevets DA, Leenen PJ, Greenfield RA (2004) Invasion of the central nervous system by intracellular bacteria. Clin Microbiol Rev 17(2):323-347

87. Nathan C, Xie QW (1994) Regulation of biosynthesis of nitric oxide. J Biol Chem 269(19):13725-13728

88. Kamijo R, Harada H, Matsuyama T, Bosland M, Gerecitano J, Shapiro D, Le J, Koh SI, Kimura T, Green SJ et al (1994) Requirement for transcription factor IRF-1 in NO synthase induction in macrophages. Science 263(5153):1612-1615

89. Koide N, Mu MM, Hassan F, Islam S, Tumurkhuu G, Dagvadorj J, Naiki Y, Mori I, Yoshida T, Yokochi T (2007) Lipopolysaccharide enhances interferon-gamma-induced nitric oxide (NO) production in murine vascular endothelial cells via augmentation of interferon regulatory factor- 1 activation. J Endotoxin Res 13(3):167-175. doi:10.1177/0968051907080894

90. Turco J, Winkler HH (1986) Gamma-interferon-induced inhibition of the growth of Rickettsia prowazekii in fibroblasts cannot be explained by the degradation of tryptophan or other amino acids. Infect Immun 53(1):38-46

91. Feng HM, Walker DH (2000) Mechanisms of intracellular killing of Rickettsia conorii in infected human endothelial cells, hepatocytes, and macrophages. Infect Immun 68(12):6729-6736

92. Billings AN, Feng HM, Olano JP, Walker DH (2001) Rickettsial infection in murine models activates an early anti-rickettsial effect mediated by NK cells and associated with production of gamma interferon. Am J Trop Med Hyg 65(1):52-56

93. Mazurier F, Fontanellas A, Salesse S, Taine L, Landriau S, Moreau-Gaudry F, Reiffers J, Peault B, Di Santo JP, de Verneuil H (1999) A novel immunodeficient mouse model-RAG2 x common cytokine receptor gamma chain double mutants-requiring exogenous cytokine administration for human hematopoietic stem cell engraftment. J Interferon Cytokine Res 19(5):533-541. doi:10.1089/107999099313983

94. Rollwagen FM (1988) Role of natural killer cells in the early clearance of Rickettsia typhi in mice. Adv Exp Med Biol 239:163-168

95. Kenyon RH, Pedersen CE Jr (1980) Immune responses to Rickettsia akari infection in congenitally athymic nude mice. Infect Immun 28(2):310-313

96. Feng HM, Whitworth T, Popov V, Walker DH (2004) Effect of antibody on the rickettsia-host cell interaction. Infect Immun 72(6):3524-3530. doi:10.1128/IAI.72.6.3524-3530.2004

97. Dumler JS, Taylor JP, Walker DH (1991) Clinical and laboratory features of murine typhus in south Texas, 1980 through 1987. JAMA 266(10):1365-1370

98. Fournier PE, Jensenius M, Laferl H, Vene S, Raoult D (2002) Kinetics of antibody responses in Rickettsia africae and Rickettsia conorii infections. Clin Diagn Lab Immunol 9(2):324-328

99. Feng H, Popov VL, Yuoh G, Walker DH (1997) Role of T lymphocyte subsets in immunity to spotted fever group Rickettsiae. J Immunol 158(11):5314-5320

100. Fang R, Ismail N, Soong L, Popov VL, Whitworth T, Bouyer DH, Walker DH (2007) Differential interaction of dendritic cells with Rickettsia conorii: impact on host susceptibility to murine spotted fever rickettsiosis. Infect Immun 75(6):3112-3123. doi:10.1128/IAI.00007-07

101. Feng HM, Popov VL, Walker DH (1994) Depletion of gamma interferon and tumor necrosis factor alpha in mice with Rickettsia conorii-infected endothelium: impairment of rickettsicidal nitric oxide production resulting in fatal, overwhelming rickettsial disease. Infect Immun 62(5):1952-1960

102. Fossiez F, Djossou O, Chomarat P, Flores-Romo L, Ait-Yahia S, Maat C, Pin JJ, Garrone P, Garcia E, Saeland S, Blanchard D, Gaillard C, Das Mahapatra B, Rouvier E, Golstein P, Banchereau J, Lebecque $S$ (1996) T cell interleukin-17 induces stromal cells to produce proinflammatory and hematopoietic cytokines. J Exp Med 183(6):2593-2603

103. Jovanovic DV, Di Battista JA, Martel-Pelletier J, Jolicoeur FC, He Y, Zhang M, Mineau F, Pelletier JP (1998) IL-17 stimulates the production and expression of proinflammatory cytokines, IL-beta and TNF-alpha, by human macrophages. J Immunol 160(7):3513-3521

104. Chabaud M, Garnero P, Dayer JM, Guerne PA, Fossiez F, Miossec P (2000) Contribution of interleukin 17 to synovium matrix destruction in rheumatoid arthritis. Cytokine 12(7):10921099. doi:10.1006/cyto.2000.0681

105. Sylvester J, Liacini A, Li WQ, Zafarullah M (2004) Interleukin-17 signal transduction pathways implicated in inducing matrix metalloproteinase-3, -13 and aggrecanase- 1 genes in articular chondrocytes. Cell Signal 16(4):469-476

106. Koenders MI, Lubberts E, Oppers-Walgreen B, van den Bersselaar L, Helsen MM, Di Padova FE, Boots AM, Gram H, Joosten LA, van den Berg WB (2005) Blocking of interleukin-17 during reactivation of experimental arthritis prevents joint inflammation and bone erosion by decreasing RANKL and interleukin-1. Am J Pathol 167(1):141-149. doi:10.1016/S0002-9440(10)62961-6

107. Kao CY, Chen Y, Thai P, Wachi S, Huang F, Kim C, Harper RW, Wu R (2004) IL-17 markedly up-regulates beta-defensin-2 expression in human airway epithelium via JAK and NF-kappaB signaling pathways. J Immunol 173(5):3482-3491

108. Liang SC, Tan XY, Luxenberg DP, Karim R, Dunussi-Joannopoulos K, Collins M, Fouser LA (2006) Interleukin (IL)-22 and IL-17 are coexpressed by Th17 cells and cooperatively enhance expression of antimicrobial peptides. J Exp Med 203(10):22712279. doi:10.1084/jem.20061308

109. Ling WL, Wang LJ, Pong JC, Lau AS, Li JC (2013) A role for interleukin-17A in modulating intracellular survival of 
Mycobacterium bovis bacillus Calmette-Guerin in murine macrophages. Immunology 140(3):323-334. doi:10.1111/imm.12140

110. Zhang Y, Wang H, Ren J, Tang X, Jing Y, Xing D, Zhao G, Yao Z, Yang X, Bai H (2012) IL-17A synergizes with IFNgamma to upregulate iNOS and NO production and inhibit chlamydial growth. PLoS One 7(6):e39214. doi:10.1371/journal. pone.0039214

111. Cai CW, Blase JR, Zhang X, Eickhoff CS, Hoft DF (2016) Th17 cells are more protective than Th1 cells against the intracellular parasite Trypanosoma cruzi. PLoS Pathog 12(10):e1005902. doi:10.1371/journal.ppat.1005902

112. Slauch JM (2011) How does the oxidative burst of macrophages kill bacteria? Still an open question. Mol Microbiol 80(3):580583. doi:10.1111/j.1365-2958.2011.07612.x

113. Stange J, Hepworth MR, Rausch S, Zajic L, Kuhl AA, Uyttenhove C, Renauld JC, Hartmann S, Lucius R (2012) IL-22 mediates host defense against an intestinal intracellular parasite in the absence of IFN-gamma at the cost of Th17-driven immunopathology. J Immunol 188(5):2410-2418. doi:10.4049/ jimmunol.1102062

114. Ouyang W, Kolls JK, Zheng Y (2008) The biological functions of T helper 17 cell effector cytokines in inflammation. Immunity 28(4):454-467. doi:10.1016/j.immuni.2008.03.004

115. Trajkovic V, Stosic-Grujicic S, Samardzic T, Markovic M, Miljkovic D, Ramic Z, Mostarica Stojkovic M (2001) Interleukin-17 stimulates inducible nitric oxide synthase activation in rodent astrocytes. J Neuroimmunol 119(2):183-191

116. LeGrand A, Fermor B, Fink C, Pisetsky DS, Weinberg JB, Vail TP, Guilak F (2001) Interleukin-1, tumor necrosis factor alpha, and interleukin-17 synergistically up-regulate nitric oxide and prostaglandin E2 production in explants of human osteoarthritic knee menisci. Arthritis Rheum 44(9):20782083. doi:10.1002/1529-0131(200109)44:9<2078:AIDART358>3.0.CO;2-J

117. Yoon HJ, Lee MS, Ki M, Ihm C, Kim D, Kim Y, Yoo SM (2010) Does IL-17 play a role in hepatic dysfunction of scrub typhus patients? Vector Borne Zoonotic Dis 10(3):231-235. doi:10.1089/vbz.2008.0149

118. Woodward TE (1982) Murine and epidemic typhus rickettsiae: how close is their relationship? Yale J Biol Med 55(3-4):335-341

119. Jerrells TR, Jarboe DL, Eisemann CS (1986) Cross-reactive lymphocyte responses and protective immunity against other spotted fever group rickettsiae in mice immunized with Rickettsia conorii. Infect Immun 51(3):832-837

120. Feng HM, Walker DH (2003) Cross-protection between distantly related spotted fever group rickettsiae. Vaccine 21(25-26):3901-3905

121. Valbuena G, Jordan JM, Walker DH (2004) T cells mediate cross-protective immunity between spotted fever group rickettsiae and typhus group rickettsiae. J Infect Dis 190(7):1221-1227. doi: $10.1086 / 423819$

122. Gazi M, Caro-Gomez E, Goez Y, Cespedes MA, Hidalgo M, Correa P, Valbuena G (2013) Discovery of a protective Rickettsia prowazekii antigen recognized by CD8+ T cells, RP884, using an in vivo screening platform. PLoS One 8(10):e76253. doi:10.1371/journal.pone.0076253

123. Caro-Gomez E, Gazi M, Goez Y, Valbuena G (2014) Discovery of novel cross-protective Rickettsia prowazekii T-cell antigens using a combined reverse vaccinology and in vivo screening approach. Vaccine 32(39):4968-4976. doi:10.1016/j. vaccine.2014.06.089

124. Li Z, Diaz-Montero CM, Valbuena G, Yu XJ, Olano JP, Feng HM, Walker DH (2003) Identification of CD8 T-lymphocyte epitopes in OmpB of Rickettsia conorii. Infect Immun 71(7):3920-3926

125. Hickman CJ, Stover CK, Joseph SW, Oaks EV (1991) Molecular cloning and sequence analysis of a Rickettsia tsutsugamushi $22 \mathrm{kDa}$ antigen containing B- and T-cell epitopes. Microb Pathog 11(1):19-31 